\title{
Systematic Approach as a Methodological Basis for Personal-Oriented Psychological Research
}

\author{
Igor Shelechov \\ Tomsk State Pedagogical University \\ Tomsk, Russia \\ bref@sibmail.com \\ Oksana Zharkova \\ National Research Tomsk State University, TSU \\ Tomsk, Russia \\ osz@tpu.ru \\ Irina Dubinina \\ National Research Tomsk State University, TSU \\ Tomsk, Russia \\ dubinina@tpu.ru
}

\author{
Ludmila Petrova \\ State University of Humanities and Technology \\ Orekhovo-Zuyevo, Russia \\ plandr50@mail.ru \\ Galina Belozerova \\ Tomsk State Pedagogical University \\ Tomsk, Russia \\ 2ww2@rambler.ru \\ Elena Berestneva \\ National Research Tomsk Polytechnic University \\ Tomsk, Russia
}

\begin{abstract}
This article describes the different aspects of a systematic and a structural-level approach that is considered as the methodological basis for personal-oriented psychological research. The general provisions of the system theory was given, and the following approaches were described: systematic approach of B. F. Lomov, systemic structural-level approach of M. S. Rogovin, D. V. Zalevskii, systemic personality-oriented approach. The concepts described can be applied in the study of the individual, the interaction of the system-"individual" "society"; the study of the selected, relatively narrow topics such as family psychology, reproductive behavior and maternal function, phenomena of internal and interpersonal conflict. The following conclusions are drawn from the comparison and analysis of data. The organization of scientific research and psychological practices based on the principles of a systematic approach enables the most comprehensive examination of certain aspects of the psyche, the comparison of empirical research data and the integration of these into a single gnosiological system to understand the phenomenology of mental processes, to look holistically at the interaction between the psyche and the surrounding world. In contrast to the individual approach, the systematic personal-oriented approach to research and psychological correction implies a mandatory reliance on the personality structure: (core, surface structures (shell), biological basis), personality orientation, and designation of future development.
\end{abstract}

Keywords - methodology of science, psychology, approach, system, structure, level, element, personality, research.

\section{INTRODUCTION}

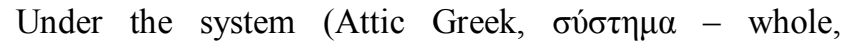
composed of parts) refers to the many constituent elements that are in relationships and relationships with each other. The following system rankings are highlighted:

- A subsystem is a system that is a part of another system and which is capable of performing a relatively independent function with subgoals to achieve the overall goal of the system.

- $\quad$ Supersystem is a larger system, part of which is the system being viewed.

The system has a number of properties that can be grouped into groups:

\section{Properties related to system goals and functions}

1. Emergence is the presence of some special properties in the system, specific set of properties that are not common for its subsystems and blocks, and the sum of elements not associated with special backbone links; irreducibility of system properties to the sum of its component properties.

2. Synergy (Attic Greek ovv-a prefix with a meaning of value $+\ddot{\varepsilon} \rho$ pov - case, work) - the maximum effect of the system is achieved only if the joint operation of its elements is as effective as possible to achieve the overall objectives.

3. Purpose mens that the system has a goal (goals) and a priority for the system's goals before its elements.

4. Alternative to the operation and development of the system. 


\section{Properties related to the system structure}

1. Structure: the decomposition of the system into individual elements and establishment of relationships between them is possible.

2. Hierarchy: each component of the system can be considered as a system; the system itself can also be seen as an element of some supersystem.

3. Self-organisation is the process of arranging elements of one level of the system due to the internal factors, without an external specific influence (the changing of external conditions can also be a stimulating effect). The result of the system's organization is the next quality level (or element).

4. The flexibility of the system is the possibility for reversible deformation under the influence of external factors.

5. According to the system theory, about $80.0 \%$ of the uneven activity of system elements is active, $20.0 \%$ is passive.

Properties related to the system resources and how they interact with the environment

1. Communication is the existence of a complex system of communications with the environment as a hierarchy.

2. Adaptivity is a tendency for a stable equilibrium state (homeostasis), which involves adapting to the system's parameters to the changing parameters of the ambient environment (but "instability" is not always dysfunctional to the system, it can also serve as a condition for dynamic development.

3. Reliability is the ability of the system to maintain its level of quality of operation within a specified period of time.

4. The system may have an internal energy factory $\left(E_{\text {internal }}\right)$ or receive external energy $\left(E_{\text {external }}\right)$.

5. interactivity (Latin, inter - between, within + activus - active) is the principle of organization of the system, in which the purpose is achieved through the information exchange of the elements of the system.

6. Isolation is a property that defines the existence of a system boundaries with a surrounding environment.

The purpose of systematic research is to build a theoretical basis, organize and conduct an empirical research, and obtain conclusions containing new gnosiological models.

The overall objectives of the systematic research are the analysis and synthesis of systems.

1. In the analysis process, the system is highlighted from the environment. The elements, structure, functions, and integral characteristics of the system are being defined. The system factors, system properties, and environment-related relationships are being viewed.

2. The system model is created during the synthesis process. It defines its composition, features, patterns, dynamics, and interactions with the environment. THeoretical bases and approaches to the description of the system are being discussed.

Using system methods enables you to systematics, planning, and organization of a comprehensive study.

\section{CLASSIFICATION AND APPLICATION OF THE SYSTEMATIC APPROACHES.}

The systematic approach applies to objects that are characterized by structural or functional isolation. On the basis of the criteria for the boundaries of the cases studied, four types of system approaches are allocated (see table 1).

TABLE I. CLASSIFICATION OF SYSTEMATIC APPROACHES

\begin{tabular}{|c|c|c|}
\hline \multirow{2}{*}{$\begin{array}{l}\text { Type of the } \\
\text { systematic } \\
\text { approach }\end{array}$} & \multicolumn{2}{|c|}{ Boundaries of the phenomena studied } \\
\hline & Are being viewed & Aren't being viewed \\
\hline Integrated & $\begin{array}{l}\text { Structure of the } \\
\text { system }\end{array}$ & $\begin{array}{l}\text { Relationships between items, } \\
\text { system properties, and its } \\
\text { interaction } \quad \text { with the } \\
\text { environment }\end{array}$ \\
\hline Structural & $\begin{array}{lr}\text { System } & \text { structure, } \\
\text { relationships } & \text { between } \\
\text { elements } & \end{array}$ & $\begin{array}{lcr}\text { System } & \text { properties, } & \text { its } \\
\text { interaction } & \text { with } & \text { the } \\
\text { environment } & & \end{array}$ \\
\hline Coherent & $\begin{array}{lr}\text { System } & \text { structure, } \\
\text { relationships } & \text { between } \\
\text { elements, } & \text { system } \\
\text { properties, } & \text { its } \\
\text { interaction with the } \\
\text { environment }\end{array}$ & Interaction between systems \\
\hline Integrated & $\begin{array}{l}\text { Intersystemal } \\
\text { interaction, } \\
\text { interinfluence }\end{array}$ & \begin{tabular}{l}
\multicolumn{2}{c}{ Internal interaction } \\
between elements of each \\
system
\end{tabular} \\
\hline
\end{tabular}

In psychology, a systematic approach is used to investigate individual objects and their elements, multiple objects, complex, multivalued phenomena, such as:

- $\quad$ the highest mental functions;

- $\quad$ structure of the individual;

- $\quad$ phenomena of internal and interpersonal conflict;

- interaction of the system "individual" "society";

- $\quad$ interaction of the system "organism" - "psyche" - "environment";

- $\quad$ family relationships;

- $\quad$ reproductive behaviour and maternal function;

- $\quad$ assessment of somatic and psychological health.

The principle of systemacity allows us to analyse individual elements of the psyche in connection with its holistic operation.

The general provisions of the system theory serve as a basis for the systematic approach proposed by B. F. Lomov [1]. A Soviet psychologist, a specialist in general and 
Pedagogical Psychology B. F. Lomov (1927-1989) had developed a number of theoretical and methodological approaches in the psychological sciences, in particular the designation of the principles of systemacity and the systemic approach as the key tools for acquiring new knowledge. B. F. Lomov considered mental processes to be systematic in nature, intrinsically inscribed in the universal relationship of the phenomena and processes of the material world. According to B. F. Lomov [1], we can understand the phenomenology of mental processes only through by analysing them in a multitude of external and internal relationships in which the mentality is a holistic system.

Justifying this approach, B. F. Lomov considered that the mentality acts as a reflection of reality and relation to it as a natural, social, conscious and unconscious. According to B. F. Lomov, Psyche is a multidimensional, hierarchically organized, dynamically integrated entity, in other words it represents a system. This implies the poly-systemacity of human existence and the integrity of his mental properties. By B. F. Lomov [1], the core of the systematic approach forms six basic principles:

1. Mental phenomena are perceived from several sides: as some qualitative unit, as an internal condition for the relationship and interaction of an object with the environment, as a collection of qualities acquired by the individual and as a result of the activity of the organism's microsystems. A holistic description of the phenomenon involves a combination of all aspects of the study.

2. Mental phenomena are multidimensional and therefore should be considered in different measurement systems. If they are to be examined on the one hand, the phenomenon would never be examined in its entirety.

3. The mental health system consists of many levels, and the psyche is generally divided into cognitive, communicative, and regulatory, each of which is also divided into levels.

4. Human properties are organized into a single whole, in a structure resembling a pyramid: the main mental processes and socio-psychological phenomena are at the top, their physiological processes are at the bottom, and the facets symbolize different categories of human properties. In this way, the system review needs to take into account a combination of different order properties.

5. A holistic knowledge of a mental phenomenon involves a multiplicity of its determinants. These include causal relationships, general and special conditions for mental phenomenon, mediating links, and external and internal factors. The same determinants may, in some circumstances, act as preconditions and in others as for example, a factor or mediating link.

6. It is best to study the mental phenomena in their dynamics. The integrity and differentiation of the individual's mental development, considered as a poly-systematic process, can be reflected in the shift of phases: impllications, emergence, formation, conversion, possible loss of individual properties and qualities.
B. F. Lomov meant studying the nature of the psyche, knowing its mechanisms and laws as the main objective of psychological Science. The diversity of existing laws and their different orientations contribute to the variability of mental phenomena. Each group of laws records a substantial and sustainable relationship of the mentality in any area. Psychological laws relate to the hierarchy of levels of mental health and reveal its specific aspects.

B. F. Lomov suggested a high-level concept for the organization of human exploration and its psyche:

- $\quad$ Level 1 (the lowest). The basic level studies are concentrated on the physiological management of mental processes and neurodynamics. This level refers to the interrelated relationships of psychology with histology, anatomy, neurochemistry, neurophysiology, neurology, genetics, anthropology, and biology.

- $\quad$ Level 2. Individual mental processes (sensation, perception, attention, memory, imagination, emotion, feelings, cogitation, speech, consciousness), mental state (being awake, asleep, stressed), mental properties (tendency to organization, intellect, presence of archetypes). At this level, psychology is linked to Mathematics, Physics, Chemistry.

- Level 3. Individual is considered in terms of its structure and individual properties. For the study of the individual as an ideal entity, there are objectively existing phenomena (activities and individual behavioural reactions).

- $\quad$ Level 4 (the highest). A person is regarded as a person in a system of social relations. The subject of the study at the highest level is personal development and sociopsychological phenomena.

The proposed level sensitive concept of the organization of human and psychological research gives the reason to systematize the data received by the psychology and defines its relationship with related areas of knowledge. Systematic approach of B. F. Lomov [1] has been further developed within a systematic structural-tier approach that serves as a means of explaining psychological phenomena $[2 ; 3]$.

The methodological basis for the study is the systemic structured approach proposed by M. S. Rogovin and G. V. Zalewskii. A special place in the work of M. S. Rogovin in the last period of his scientific activities took the interest in building a common psychological structure theory and the possibility of introducing it into a clinic-psychological research and practice [4-10]. The psychological theory of the leveled structure encompasses both mental processes and behavioural reactions. In Aristotle's Treatise "On the soul"


in the methodological, theoretical and applicational relationship from the mentality as a complex integrity to the attempt to analyse it as a hierarchical level structure. This tendency, sometimes being explicitly but often implicitly, is evident throughout the history of psychology (in particular clinical psychology, pathopsychology). There is reason to believe that it is only now that this well-established methodological approach to the organization of scientific research is acquiring an adequate conceptual apparatus and 
corresponding terminology [10-12].

In Russian psychology, the greatest contribution to the structural and psychological understanding was made by psychophysiologist N. A. Bernstein, who had developed the concept of "act" [13-16], on the basis of the data on the construction of movements. A psychologist, a philosopher, a teacher, has developed this theory on a number of issues. N. Leontiev [17].

Some foreign researcher such as a French neurologist and psychiatrist P. Jean (French Pierre-Marie-Félix Janet), who played a central role in the development of the structure theory and who suggested the hierarchical system of behavior: from elementary reflexive acts to higher intellectual activity [18; 19].

For several years, M. S. Rogovin and his disciples have carried out research in various fields of psychology, the results of which have been interpreted in terms of this theory, thus broadening and refining its starting points [4-8].

The main points of the structure theory. For the brevity, this is done in the form of talking points [7]:

1. About mental (as internal mechanisms) we have been judged on the basis of the tiered structure of action (actional levels). Level is such a psychological correlation between the characteristics of actions and the mental processes that determine them (private structure in general activity and personality structures), which, in relation to other action structures possible in the same situation makes it possible to judge the adequacy of the target's purpose.

2. Actions form a certain (and at the same time dynamic) hierarchical structure where the highest, guiding, and regulatory level is the goal.

3. In relation to higher actional levels, inferiors are the means of their realization.

4. Higher actional levels are, as a rule, levels that are more integrated in the individual.

5. The differentiation of higher actional levels is usually clearer than at relatively lower levels.

6. The highest level is not just a goal level, but it is also necessary to treat the underlying levels adequately.

7. Lower levels are on the brink of physiology, and psychological levels begin with object conditionality.

8. Relationships between actional levels are dialectic: higher may manifest itself as the inferior and lower as the higher levels. Higher levels may be positive or negative (as a negation of the inadequacy of the whole structure).

9. The number of actional levels (that is, the number of levels in the interval between the lowest and highest) is an unstable value. It is due to the specific situation of the study (task, conditions, contingent of surveyed, etc.).

10. The transition from the lowest actional level to the higher is due to many reasons: greater awareness of the task, its new, more complete understanding, training, and the development of a skill or intuitive solution.
11. The transition from a higher actional level to the lowest can occur as a result of the complexity of the task, the disintegration of the existing skill or the mental pathology.

12. Factors such as stress or communication can affect actional levels, but specific research is needed to define them in each case.

13. In the formation of higher actional levels, knowledge is more important than in the form of inferiority.

14. The statement of actional levels implies some optimum range of their common flexibility, because locking one of them might break the overall structure.

15. The use of a actional level in reaching the target is due in large part to the degree of uncertainty in the stimulation. The lower the actional level, the greater the variability and the higher the level, the less the uncertainty is. Moving from lower levels to a higher one reduces the uncertainty of stimulation, but the incomplete exhaustion of information at each level increases the risk of an erroneous problem solving.

It should be noted that a systematic structured approach to psychological and behavioural research can reveal patterns in the psychosocial aspects of reproductive and, in particular, the maternal function as a structural phenomenon, identify mechanisms for the emergence of deviant forms of maternal behaviour and develop effective methods for their correction.

\section{A systemic personality-oriented approach.}

The most promising and ethically predominant position in examining the reproductive function of women is to focus the research on the personality structure as the main determinant of the implementation of the reproductive behaviour and, in particular, the maternal function. This position, which can be presented as a systematic, personal-oriented approach, has not only a scientific but also a practical meaning: It allows to conduct a psychological correction of identified reproductive behavioural deviations, relying on personal resources and the "healthy part of the individuality" of the client.

The term "personality-oriented approach" has been widely disseminated in psychology, medicine, education and social research, in particular in relation to marriage and family relations.

The ideas of a personal-oriented approach were put forward by the creators and leading representatives of the humanistic psychology of the 1960s. by American psychologist K. R. Rogers ( Carl Ransom Rogers; 1902-1987) and A. H. Maslow ( Abraham Harold Maslow; 1908-1970). The humanistic direction in psychology has emerged as opposed to the doctrine of the behavioural response of individuals - behaviorism. As part of this approach, a person was viewed as a biological material system that reacts to external stimuli, without taking into account personal characteristics and social factors. In addition, it was considered permissible to transfer to people results acquired by conducting experiments on animals. Human psychologists have set the goal of a personal-oriented approach to change the image of a man and his nature [21-29]. 
Thanks to the scientific and practical work of K. R. Rogers and his followers, the humanistic stance is now being pursued through a personal-oriented approach that affects not only psychological science but also the broad aspects of social life of society.

A personal-oriented approach, based on the fact that the individual is the unity of the mental characteristics that make up her identity, implements its technology as an important methodological principle of the individual approach that Interpretations of data from psychodiagnostic studies and subsequent rehabilitative activities take into account the individual characteristics of each woman as the subject of reproductive behaviour. This creates, in our view, the optimal conditions for promoting the personal development of the client and the successful conduct of psychological activities [22-29].

\section{CONCLUSION.}

The organization of scientific research and psychological practices based on the principles of a systematic approach enables the most comprehensive examination of certain aspects of the psyche, the comparison of empirical research data and the integration of these into a single gnosiological system to understand the phenomenology of mental processes, to look holistically at the interaction between the psyche and the surrounding world.

In contrast to the individual approach, the systematic personal-oriented approach to research and psychological correction implies a mandatory reliance on the personality structure: (core, surface structures (shell), biological basis), personality orientation, and designation of future development.

\section{REFERENCES}

[1].

Lomov B. F. Sistemnost' $v$ psihologii [Consistency in psychology]. Moscow: Institute of Applied Psychology; Voronezh: NPO «MODEK», 1996. 384 p. (in Russian).

[2]. Berestneva O. G., Shelekhov I. L., Urazaev A. M. Sistemnye issledovanija $\mathrm{i}$ informacionnye tehnologii $\mathrm{v}$ zadachah izuchenija social'no-psihologicheskih aspektov reproduktivnoj funkcii zhenshhin: Kollektivnaja monografija [System research and information technologies in the study of problems of socio-psychological aspects of women's reproductive function: collective monograph]. Tomsk: Publishing house of Tomsk State. ped. University Press, 2010. 188 p. (in Russian).

[3].

Shelekhov I. L., Berestneva O. G. Reproduktivnoe zdorov'e zhenshhiny: psihologicheskie i social'nye aspekty: Monografija [Reproductive health in women: psychological and social aspects: Monograph]. Tomsk: Publishing house of Tomsk Polytechnic. University Press, 2013. 366 p. (In Russian).

[4]. Rogovin M. S. Razvitie strukturno-urovnevogo podhoda $v$ psihologii // Sistemnye issledovanija. Ezhegodnik [The development of structure-level approach in psychology] // System Research. Yearbook. Moscow: Nauka, 1974, pp. 187-230. (In Russian).

[5]. Rogovin M. S. Strukturno-urovnevye teorii v psihologii: metodologicheskie osnovy [Structurally-level theory in psychology: methodological bases]. Yaroslavl: Yaroslavl State University, 1977. 79 p. (In Russian).

[6]. Rogovin M. S. Psihologicheskoe issledovanie [Psychological research]. Yaroslavl: Yaroslavl State University, 1979. 66 p. (In Russian).
[7]. Rogovin M. S. Osnovnye polozhenija obshhepsihologicheskoj strukturno-urovnevoj teorii // Poznavatel'nye processy i lichnost' $\mathrm{v}$ norme i patologii [Main provisions of the general psychological theory of structural-level // Cognitive processes and personality in health and disease]. Yaroslavl: Yaroslavl State University, 1995, pp. 10-12. (In Russian).

[8]. Rogovin M. S., Zalevskij G. V. Teoreticheskie osnovy psihologicheskogo i patopsihologicheskogo issledovanija [Theoretical bases of psychological and patopsihologicheskogo research]. Tomsk: Tomsk University Press, 1988, 233 p. (In Russian).

[9]. Zalevskij G. V. Fiksirovannye formy povedenija individual'nyh i gruppovyh sistem (v kul'ture, obrazovanii, nauke, v norme i patologii) [Fixed forms of individual and group behavior systems (culture, education, science, health and disease)]. Tomsk: Publishing house of Tom. state. University Press, 2004, 446 p. (In Russian).

[10]. Zalevskij G. V. O nauchnom nasledii M. S. Rogovina [On the scientific heritage of M. S. Rogovin] // Methodology and history of psychology. 2006, vol 1, Issue. 2, pp. 99-102. (In Russian).

[11]. Shelekhov I. L., Zalevskij G. V. Lichnost' sovremennoj zhenshhiny cherez prizmu sistemnoj strukturno-urovnevoj koncepcii psihiki [The identity of the modern woman through the lens system-level structural concepts of the psyche psychological] // Siberian psychological journal. 2010, № 36, pp. 36-41. (In Russian).

[12]. Shelekhov I. L., Zalevskij G. V. Lichnostnye aspekty reproduktivnogo povedenija, kak sistemnogo strukturno-urovnevogo fenomena [Personal aspects of reproductive behavior, as a system of structurally-tiered phenomenon] // Siberian psychological journal. 2010, № 37, pp. 6-10. (In Russian).

[13]. Bernshtejn N. A. Issledovanija po biodinamike lokomocij. Kn. 1. Biodinamika hod'by normal'nogo vzroslogo muzhchiny [Research on biodynamics locomotion. Bk. 1. Biodynamics normal adult male walking]. Moscow: VIEM (All-Union Institute of Experimental Medicine), 1935, 242 p. (In Russian).

[14]. Bernshtejn N. A. O postroenii dvizhenij [About construction of movements]. Moscow: Medgiz, 1947, 254 p. (In Russian).

[15]. Feigenberg J. M. Nikolai Bernstein - From Reflex to the Model of the Future: Monographie. Münster: LIT Verlag, 2014. 272 p.

[16]. Feigenberg J., Zislin J. «Receptor component» and «active component» in the psychology and psychopathology of perception // Medical Hypotheses. Vol. 54. Issue 2, February 2000, pp. 169-171.

[17]. Leont'ev A. N. Dejatel'nost'. Soznanie. Lichnost' [Activities. Consciousness. Personality]. Moscow: Politizdat, 1975. 304 p. (In Russian).

[18]. Janet P. La médecine psychologique [Psychological Medicine]. Paris: Flammarion, 1923. 288 p.

[19]. Janet P. L'évolution psychologique de la personnalité. Paris: Éditions Chahine, 1929. 327 p.

[20]. Rogovin M. S., Solov'jov A. V., Urvancev L. P. Urovnevaja struktura dejstvija [The layered structure of action] // Psychological rationalization activities. Yaroslavl: Yaroslavl State University, 1978, pp. 10-21. (In Russian).

[21]. Karpov A. V. Psihologija prinjatija reshenij: Monografija [The psychology of decision-making: Monograph]. Moscow, Yaroslavl: Institute of Psychology RAS, 2003. 272 p. (In Russian).

[22]. Kozlov V. V. Integrativnaja psihologija. Teorija i psihotehnika: Metodicheskoe posobie [Integrative Psychology. Theory and psycho: Toolkit]. Yaroslavl: [no publishers], 2004. 120 p. (In Russian).

[23]. Mazilov V. A. Metodologija psihologii: tochki rosta [Methodology of psychology: the growing point] // Yaroslavsky Psychological Bulletin. Moscow-Yaroslavl, 2009, vol. 25, p. 48. (in Russian).

[24]. Berestneva O. G., Zharkova O. S., Shelekhov I. L. Sistemnyj analiz i informacionnye tehnologii $\mathrm{v}$ zadachah issledovanija gendernyh $\mathrm{i}$ lichnostnyh osobennostej sovremennyh zhenshhin: Monografija [System analysis and information technologies in the problems of the study of gender and personality characteristics of modern women: Monograph]. 
Tomsk: Publishing house of Tom. Polytechnic. University Press, 2013. 294 p. (In Russian).

[25]. Shelehov I. L., Grebennikova E. V. Il comportamento riproduttivo delle donne come sistemica a livello strutturale fenomeno // Italian Science Review. 2015, vol. 5(26), pp. 51-57. Available at URL: http://www.ias-journal.org/archive/2015/may/Shelehov.pdf.

[26].

Ivankina L. I. , Berestneva O. G. , Shelekhov I. L. View of young people of the modern Russian society on predominant values of partnership in marriage (on the basis of survey) // Procedia - Social and Behavioral Sciences. - 2015 - Vol. 166. - p. 2-6

[27]. Karpov A. V. Metasistemnyj podhod i psihologija soznanija. Monografija [Metasystem approach and the psychology of consciousness. Monograph]. Moscow: Publishing House of the RAO, 2011, 1023 p. (In Russian).

[28]. Kozlov V. V. Gruppovaja rabota. Strategija i metody issledovanija [Group work. Strategy and research methods]. Moscow: Publishing House of the Institute of Psychotherapy, 2007. 224 p. (In Russian).

[29]. Kashapov M. M. Konsul'tacionnaja rabota psihologa: Uchebnoe posobie [Consulting work of psychologist: Textbook]. Yaroslavl: Yaroslavl State. University Press, 2005. 196 p. (In Russian). 